\title{
KARAKTERISTIK FISIK DAN SENSORI MINUMAN SARI BUAH PEDADA
}

\author{
Dini Wulan Dari*, Dini Junita \\ Program Studi Ilmu Gizi, Sekolah Tinggi Ilmu Kesehatan Baiturrahim Jambi, \\ Jalan Prof. DR. Moh. Yamin No.30, Lb. Bandung, Kecamatan Jelutung, Kota Jambi 36135 \\ Diterima: 23 September 2020/Disetujui: 23 Desember 2020 \\ *Korespondensi: wulandaridini62@gmail.com
}

Cara sitasi: Dari DW, Junita D. 2020. Karakteristik fisik dan sensori minuman sari buah pedada. Jurnal Pengolahan Hasil Perikanan Indonesia. 23(3): 532-541.

\begin{abstract}
Abstrak
Pedada (Sonneratia caseolaris) merupakan buah tanaman mangrove yang memiliki kandungan gizi tinggi, banyak terdapat di Tanjung Jabung Barat, Jambi. Potensi gizi tersebut dapat dimanfaatkan melalui upaya diversifikasi pangan menjadi produk sari buah. Tujuan penelitian ini yaitu menentukan formulasi sari buah pedada terbaik dengan perbandingan pedada dan gula. Perlakuan yang digunakan berdasarkan penelitian pendahuluan yaitu proporsi pedada dan gula menggunakan enam perlakuan yaitu P1 (pedada $150 \mathrm{~g}$ : gula $0 \%$ ), P2 (pedada $150 \mathrm{~g}$ : gula 60\%), P3 (pedada $150 \mathrm{~g}$ : gula 70\%), P4 (pedada $200 \mathrm{~g}$ : gula $0 \%$ ), P5 (pedada $200 \mathrm{~g}$ : gula 60\%) dan P6 (pedada $200 \mathrm{~g}$ : gula 70\%). Parameter yang diamati yaitu sensori, nilai pH, viskositas dan nilai $L^{*}$. Data diuji statistik menggunakan analisis ragam two way anova. Hasil penelitian sari buah pedada dengan komposisi 200 g pedada dan penambahan gula 70\% memiliki karakteristik terbaik. Karakteristik fisik sari buah pedada terbaik secara sensori yaitu warna dan aroma agak disukai, rasa manis asam, tekstur cair, penerimaan secara keseluruhan disukai, memiliki nilai pH 3,20 (asam), viskositas 2,88 cp, dan nilai $L^{\star} 47,19$ (mendekati cerah).
\end{abstract}

Kata kunci: formula terbaik, gula, pedada, sensori, Sonneratia caseolaris

\section{Physical and Sensory Characteristics of Pedada Juice}

\section{Abstract}

Sonneratia caseolaris or known as Firefly Mangrove, or Mangrove Apple is an evergreen, tropical, commonly in Tanjung Jabung Barat, Jambi Province. The nutritional content in $100 \mathrm{~g}$ of pedada consists of $9.21 \%$ protein, $4.81 \%$ fat, $77.57 \%$ carbohydrates and $56.74 \mathrm{mg}$ of vitamin C. The nutritional potential can be exploited through efforts to diversify food into fruit juice drinks. Knowing the effect of adding pedada and sugar proportions on the physical and sensory characteristics of pedada juice and determining the best pedada juice formulation is the aim of this study. The treatment used was based on preliminary research was the proportion of pedada and sugar using six treatments was P1 (pedada $150 \mathrm{~g}: 0 \%$ sugar), P2 (pedada 150 g: sugar $60 \%$ ), P3 (pedada 150 g: 70\% sugar), P4 (200 g of pedada: $0 \%$ sugar), P5 (200 g of pedada: $60 \%$ sugar) and P6 (200 g of pedada: 70\% sugar). Data were statistically tested using two way ANOVA analysis. The results of the study of pedada juice with the composition of $200 \mathrm{~g}$ of pedada and the addition of $70 \%$ sugar had the best characteristics. The best physical characteristics of pedada fruit juice have a $\mathrm{pH}$ value of 3.20 (acid), viscosity $2.88 \mathrm{cp}$, and an $L^{*} 47.19$ value (close to bright). The best sensory characteristics of pedada juice are the preferred color and odor, sweet and sour taste, liquid texture, overall acceptance is preferred.

Keyword: best formula, sugar, pedada, sensory, Sonneratia caseolaris 


\section{PENDAHULUAN}

Indonesia memiliki hutan mangrove terbesar di dunia termasuk hutan mangrove Provinsi Jambi, tepatnya di wilayah pesisir Kabupaten Tanjung Jabung Barat. Pedada (Sonneratia caseolaris) merupakan buah hasil tanaman mangrove. Buah pedada yang sudah matang memiliki rasa asam dan aroma yang menarik serta kaya akan kandungan serat, mineral, dan makronutrien. Buah pedada segar hasil tanaman mangrove Kabupaten Tanjung Jabung Barat diketahui mengandung air $67,8 \%$, abu $1,17 \%$, protein $3,45 \%$, karbohidrat 26,89\%, dan vitamin C $66 \mathrm{mg} / 100$

g (Ramadani et al. 2019). Pedada segar 100 gram mengandung karbohidrat 15,95\%, lemak $0,86 \%$, abu $3,85 \%$, dan protein $2,24 \%$ (Jariyah et al. 2014), mengandung vitamin A 11,21 RE, B1 5,04 mg, B2 7,65 mg dan vitamin C 56,74 mg (Manalu et al. 2013).

Komponen bioaktif berupa fitokimia juga ada dalam buah pedada yaitu flavonoid, tanin, fenol, saponin, triterpenoid, steroid, alkaloid, serat yang larut dan yang tidak larut yang bermanfaat bagi kesehatan (Ahmed et al. 2010; Jariyah et al. 2014; Jariyah et al. 2015) serta memiliki aktivitas antibakteri (Prihanto 2011). Buah pedada mengandung total pati $51,04 \%$, amilosa $24,23 \%$ dan amilopektin 26,81\% (Pradana et al. 2017). Kandungan gizi yang tinggi terdapat pada buah pedada berpotensi untuk dikembangkan menjadi produk olahan pangan, akan tetapi masyarakat belum memiliki pengetahuan yang luas tentang upaya diversifikasi olahan pangan.

Pemanfaatan buah pedada di Provinsi Jambi, khususnya di wilayah Tanjung Jabung Barat diolahan menjadi bahan pangan (Tjandra 2016), yang sudah dilakukan di antaranya sirup (Rahmadani et al. 2019), permen jeli (Rahmadani et al. 2020, Dari et al. 2020a) dan sari buah (Dari et al. 2020b). Sirup pedada memiliki rasa asam manis dengan aroma khas pedada. Produk ini berpotensi menjadi pilihan minuman penyegar namun belum praktis sehingga perlu dikembangkan diversifikasi minuman sejenisnya (Jariyah et al. 2019). Pengembangan produk yang sesuai dengan karakteristiknya yaitu minuman siap dikonsumsi berupa sari buah pedada, merupakan upaya untuk mengatasi permasalahan dan meningkatkan nilai ekonomis produk.

Sari buah merupakan olahan dari buah yang sudah dikenal oleh masyarakat. Pembuatan sari buah menggunakan bahan utama yaitu buah dan bahan tambahan yaitu air dan gula. Penambahan gula bertujuan untuk meningkatkan atau mengubah cita rasa, sumber energi akan dipergunakan oleh sel-sel, dan sebagai pengawet. Gula sebagai pengawet dengan cara mengikat kandungan air dan efek osmosisnya dapat mengurangi kadar air bahan yang diawetkan. Penambahan gula dengan jumlah tertentu dapat menghambat pertumbuhan mikroba pada bahan yang diawetkan karena adanya proses plasmolisis pada mikroba, yaitu zat cair yang terkandung dalam tubuh mikroba akan tersebar keluar dan akan disedot oleh daya osmosis dari gula (Indriaty dan Assah 2015). Penelitian yang mengkaji penggunaan gula dengan jumlah yang tepat pada pengolahan sari buah pedada hingga saat ini belum dilaporkan, sehingga penelitian ini perlu dilakukan untuk diperoleh karakteristik fisik dan sensori produk. Penelitian ini bertujuan untuk menentukan formulasi sari buah pedada terbaik dengan perbandingan pedada dan gula.

\section{BAHAN DAN METODE Bahan dan Alat}

Bahan utama yang digunakan pada penelitian ini adalah buah pedada didapatkan dari Kabupaten Tanjung Jabung Barat, Provinsi Jambi tepatnya di sekitar area kantor Diklat Kuala Tungkal, gula pasir dan air mineral. Alat-alat yang digunakan adalah $\mathrm{pH}$ meter, viskometer rotasional dial reading (Brookfield Engineering Labs Inc, US), chromameter Minolta (CR-310, Japan), kuesioner uji sensori.

\section{Pembuatan sari buah pedada}

Pembuatan produk dan analisis sensori panelis semi terlatih dilakukan di Laboratorium Gizi dan Pangan STIKes Baiturrahim, Laboratorium Jasa Analisis (LJA) Fakultas Teknologi Pertanian Institut Pertanian Bogor (IPB) untuk pengujian warna dan viskositas, dan Laboratorium Terpadu Universitas Jambi untuk analisis $\mathrm{pH}$. 
Pembuatan sari buah pedada dalam penelitian ini mengacu pada Ramadani et al. (2019) dengan modifikasi. Buah pedada dipisahkan daging dan biji serta kulit dan kelopak, ditambahkan air dengan perbandingan 1:10 (buah pedada:air) (b/v), kemudian dihaluskan dengan blender dan disaring sari buahnya. Sari buah dipanaskan selama 15 menit dan ditambahkan gula sesuai perlakuan. Perlakuan pada penelitian ini terdiri dari: $\mathrm{P} 1=$ buah pedada $150 \mathrm{~g}$ tanpa penambahan gula (kontrol); $\mathrm{P} 2=$ buah pedada $150 \mathrm{~g}$ dengan penambahan gula $60 \%$; $\mathrm{P} 3=$ buah pedada $150 \mathrm{~g}$ dengan penambahan gula $70 \%$; P4= buah pedada $200 \mathrm{~g}$ tanpa penambahan gula (kontrol); $\mathrm{P} 5=$ buah pedada 200 g dengan penambahan gula $60 \%$; dan $\mathrm{P} 6=$ buah pedada $200 \mathrm{~g}$ dengan penambahan gula $70 \%$.

\section{Karakteristik sari pedada Derajat keasaman $(\mathrm{pH})$}

Analisis derajat keasaman (nilai $\mathrm{pH}$ ) pada sari buah pedada menggunakan $\mathrm{pH}$ meter mengacu pada BSN (2004). Pengujian ini dimulai dengan penggunaan larutan penyangga untuk kalibrasi $\mathrm{pH}$ meter. Setelah alat siap digunakan, sampel sari buah pedada yang diuji diletakkan dalam wadah, kemudian elektroda dimasukkan dan ditunggu sampai angka $\mathrm{pH}$ meter stabil.

\section{Viskositas}

Analisis viskositas dilakukan untuk mengetahui tingkat kekentalan sari buah pedada agar dapat dibandingkan dengan standar viskositas minuman sari buah mengacu pada BSN (2008). Pengujian viskositas dilakukan menggunakan viskometer. Langkah uji dengan mencelupkan jarum viskometer nomor satu ke dalam larutan sampel, kemudian larutan tersebut dihisap hingga mencapai garis ke empat. Selanjutnya viskometer diletakkan dalam penangas air bersuhu $\left(25 \pm 0,1{ }^{\circ} \mathrm{C}\right)$ dan dibiarkan paling sedikit lima menit agar suhu larutan contoh uji di dalam viskometer mencapai suhu $25^{\circ} \mathrm{C}$. Kemudian larutan contoh uji dihisap, larutan contoh dibiarkan uji membasahi bagian dalam viskometer, di tahapan akhir larutan dihisap dari bola tiga hingga bola ke enam, dan dihitung waktu yang dibutuhkan untuk mengalir mulai dari garis batas 5 sampai dengan garis batas empat. Pengukuran lama alir diulang dengan ketelitian 0,2 detik.

\section{Mutu warna berdasarkan nilai $L^{*}$}

Warna sampel sari buah pedada dianalisis menggunakan kromameter (Hutching 1999). Tahapan pengujian dengan menyiapkan masing-masing sampel sebanyak $5 \mathrm{~g}$. Sebelum pengujian alat dikalibrasi dan panel standar disinar. Mata cahaya kromameter ditempelkan sedekat mungkin pada sampel dan disinari dengan alat. Hasil pengukuran warna akan tertera pada layar. Hasil yang dilihat adalah nilai $L^{*}$ yang berarti tingkat kecerahan sampel, semakin tinggi nilai yang diperoleh, semakin cerah warna sampel.

\section{Uji sensori}

Uji mutu sensori dilakukan menggunakan panelis sebanyak 60 orang yang terdiri dari panelis semi terlatih yang berasal dari mahasiswa Program Studi Ilmu Gizi STIKes Baiturrahim berjumlah 30 orang dan panelis masyarakat yang berasal dari Kuala Tungkal, Kabupaten Tanjung Jabung Barat, Provinsi Jambi berjumlah 30 orang. Kriteria panelis semi terlatih dalam penelitian ini adalah mahasiswa dari Program Studi Ilmu Gizi STIKes Baiturrahim Jambi yang telah lulus mata kuliah Teknologi Pangan dan praktik uji organoleptik, berumur 18-22 tahun, bersedia menjadi panelis, dalam kondisi sehat, mampu berkomunikasi dengan baik. Kriteria panelis masyarakat adalah warga asli Kuala Tungkal yang suka buah pedada atau olahannya, berkomunikasi dengan baik, tidak buta warna dan bisa baca tulis, sehat jasmani dan rohani, serta bersedia menjadi panelis. Pengujian organoleptik dilakukan panelis menggunakan formulir uji terhadap parameter sensori yaitu tekstur, rasa, warna, aroma dan penerimaan keseluruhan.

Sampel sari buah pedada sebanyak 6 perlakuan diberikan kepada panelis masingmasing sebanyak $50 \mathrm{~mL}$. Panelis diminta untuk menilai karakteristik sensori sampel, dan diwajibkan minum air putih setelah dan sebelum melakukan penilaian sampel selanjutnya. Nilai diberikan dalam skala 1-5 
dengan kategori penilaian sangat tidak sukasangat suka untuk parameter hedonik (warna, aroma, penerimaan keseluruhan), sedangkan untuk mutu hedonik dengan parameter rasa dengan kategori sangat asam-manis keasaman dan untuk parameter tekstur dengan kategori sangat kental-cair. Data yang telah terkumpul dari kuesioner uji hedonik dan uji mutu hedonik diolah menggunakan SPSS versi 22, dengan uji analisis of varians-two way.

\section{HASIL DAN PEMBAHASAN Karakteristik Fisik Sari Buah Pedada Derajat keasaman $(\mathrm{pH})$ sari buah pedada}

Buah pedada (Sonneratia caseolaris) memiliki ciri khas rasa yang asam sehingga banyak yang tidak menyukai buah tersebut secara langsung (Ahmed et al. 2010). Penambahan bahan-bahan dalam pembuatan sari buah pedada diharapkan dapat meningkatkan nilai $\mathrm{pH}$ sehingga akan lebih diminati. Analisis $\mathrm{pH}$ minuman sari buah pedada dengan penambahan gula yang bervariasi berkisar antara 2,95-3,20 (Table 1).

Sampel P4 (kontrol) nyata lebih asam dibandingkan sampel P3 dan P6. Derajat keasaman $(\mathrm{pH})$ suatu produk dapat ditingkatkan dengan penambahan gula. Semakin besar konsentrasi gula ditambahkan, maka sari buah pedada memiliki derajat keasaman $(\mathrm{pH})$ yang tinggi. Gula yang ditambahkan semakin banyak sejalan dengan $\mathrm{pH}$ yang meningkat. Hal ini dikarenakan ion $\left[\mathrm{H}^{+}\right]$yang membentuk asam akan berkurang, sehingga $\mathrm{pH}$ bahan akan meningkat (Pertiwi dan Susanto 2014). Kategori derajat keasaman sari buah yaitu; $\mathrm{pH}$ 0-6,4 dikategorikan asam;
$\mathrm{pH}$ 6,5-7,5 dikategorikan netral; dan $\mathrm{pH}$ 7,614 dikategorikan basa. Meskipun penambahan gula meningkatkan nilai $\mathrm{pH}$, namun $\mathrm{pH}$ semua sari buah pedada dalam penelitian ini masih dalam kategori asam $(2,95-3,20)$ (BSN 2004).

Kualitas produk pada pangan yang diolah atau diawetkan dapat dipengaruhi juga oleh nilai $\mathrm{pH}$. Perubahan nilai $\mathrm{pH}$ secara signifikan dapat mengubah rasa dan $\mathrm{pH}$ dengan kategori asam menyebabkan mikroba akan sulit tumbuh sehingga produk menjadi lebih awet (Wiyono dan Kartikawati 2017). Banyaknya kandungan asam organik menyebabkan sari buah memiliki pH yang rendah (Kiayi 2018). Nilai $\mathrm{pH}$ 3,0 dan 4,0 merupakan nilai $\mathrm{pH}$ yang umumnya terdapat pada sari buah sehingga semakin rendah nilai $\mathrm{pH}$ maka semakin awet produk tersebut. Proses pemanasan dengan waktu yang lama maupun suhu yang tinggi akan memiliki kecenderungan kenaikan $\mathrm{pH}$ dengan hilangnya asam-asam organik, di antaranya asam sitrat, asam askorbat dan asam lainnya (Rakhmawati dan Yunianta 2015).

\section{Viskositas sari buah pedada}

Hasil penelitian memperlihatkan nilai viskositas minuman sari buah pedada dengan formulasi penambahan gula berkisar antara 2,13-2,88 cP (Table 1). Sampel P5 dan P6 memiliki nilai viskositas yang nyata lebih tinggi dibandingkan sampel kontrol. Nilai viskositas bisa dipengaruhi dengan konsentrasi gula yang ditambahkan pada minuman. Konsentrasi gula semakin tinggi akan menyebabkan tingkat viskositas larutan juga semakin tinggi. Hal ini terjadi karena komponen gula yang larut memengaruhi zat

Table 1 Physical analysis of pedada juice

\begin{tabular}{ccrc}
\hline \multirow{2}{*}{ Sample } & \multicolumn{3}{c}{ Parameter } \\
\cline { 2 - 4 } & $\mathrm{pH}$ & Viscosity $(\mathrm{cP})$ & Color $\left(\mathrm{L}^{*}\right)$ \\
\hline P1 & $3.05 \pm 0.17^{\mathrm{ab}}$ & $2.33 \pm 0.03^{\mathrm{a}}$ & $45.01 \pm 0.34^{\mathrm{a}}$ \\
P2 & $3.15 \pm 0.17^{\mathrm{ab}}$ & $2.55 \pm 0.40^{\mathrm{ab}}$ & $49,16 \pm 0.80^{\mathrm{a}}$ \\
P3 & $3.20 \pm 0.12^{\mathrm{b}}$ & $2.62 \pm 0.44^{\mathrm{ab}}$ & $48.02 \pm 4.60^{\mathrm{a}}$ \\
P4 & $2.95 \pm 0.06^{\mathrm{a}}$ & $2.13 \pm 0.09^{\mathrm{a}}$ & $42.68 \pm 7.18^{\mathrm{a}}$ \\
P5 & $3.15 \pm 0.17^{\mathrm{ab}}$ & $2.85 \pm 0.06^{\mathrm{b}}$ & $46.59 \pm 5.99^{\mathrm{a}}$ \\
P6 & $3.20 \pm 0.12^{\mathrm{b}}$ & $2.88 \pm 0.43^{\mathrm{b}}$ & $47.19 \pm 2.93^{\mathrm{b}}$ \\
\hline
\end{tabular}

Note: different letter on the same column indicate a significant difference at $p<0.05$ 
organik yang terlarut juga sehingga jumlah total padatan terlarut jadi semakin tinggi. Hal tersebut menyebabkan tekstur sari buah pedada menjadilebihkentaldan meningkatkan nilai viskositas larutannya (Pratama et al. 2012). Meskipun demikian penilaian tekstur produk sari buah pedada dalam penelitian ini secara subjektif dalam uji sensori masih berada dalam kategori agak cair. Hal ini sejalan dengan Farikha et al. (2013), sari buah naga merah memperlihatkan hasil viskositas berkisar antara 1,96-3,11 cP, sedangkan pada produk sirup pedada yang dilakukan oleh Andriani et al. (2016), memperlihatkan hasil viskositas berkisar antara 188,53-202,40 cP. Nilai viskositas produk semakin tinggi, maka produk semakin kental.

\section{Warna sari buah pedada berdasarkan nilai $L^{*}$}

Berdasarkan penilaian mutu secara objektif, minuman sari buah pedada dengan berbagai variasi penambahan gula memiliki nilai kecerahan berkisar antara 42,68-49,16 cP (Table 1). Hasil analisis menunjukkan bahwa tingkat kecerahan minuman sari buah pedada tidak nyata berbeda pada semua sampel. Dilihat dari tingkat kecerahannya, minuman sari buah pedada dengan sampel P2, P3 dan P4 nyata memiliki tingkat kecerahan yang lebih tinggi dibandingkan dengan sampel P1 sebagai kontrol 1, dan sampel P6 nyata memiliki tingkat kecerahan yang lebih tinggi dibandingkan dengan sampel P4 sebagai kontrol 2. Nilai kecerahan sari buah pedada lebih rendah daripada minuman probiotik sari buah kurma yang berkisar antara 56,13 62,68 (Retnowati dan Kusnadi 2014).
Tingkat kecerahan (lightness) atau nilai $\mathrm{L}^{*}$ menyatakan warna akromatik yaitu putih, hitam, dan abu-abu. Warna hitam atau gelap dinyatakan dengan nilai 0 dan nilai 100 dinyatakan berwarna putih atau terang (Kaemba et al. 2017). Reaksi browning nonenzimatik menyebabkan perubahan warna pada minuman sari buah yang disebut sebagai reaksi Mailard, yaitu reaksi yang terjadi karena adanya gula dengan gugus amina dari asam amino, peptida atau protein yang akan membentuk browning pigment yang disebut melanoidin (Visita dan Putri 2014). Penggunaan gula yang lebih banyak mengakibatkan proses browning yang lebih tinggi sehingga sampel terlihat lebih berwarna dibandingkan dengan sampel kontrol tanpa gula.

\section{Karakteristik Sensori Sari Buah Pedada Warna sari pedada}

Warna merupakan variabel pada mutu sensori pertama yang dapat dilihat dan dinilai secara langsung oleh panelis. Warna suatu pangan akan memengaruhi mutu pangan yang ditentukan oleh panelis. Warna sari pedada disajikan pada Table 2. Tingkat penerimaan kesukaan parameter warna sampel P4 dan P1 (kontrol) nyata lebih disukai warnanya dibandingkan dengan sampel lainnya P5, P2, P3 dan P6) ditandai dengan nilai skor warna sampel P4 yaitu 3,38 dan sampel P1 yaitu 3,35 yang termasuk dalam kategori agak suka. Formulasi buah pedada $200 \mathrm{~g}$ dengan penambahan gula $0 \%$ lebih disukai panelis dikarenakan warna yang dihasilkan agak lebih disukai dibandingkan perlakuan yang lain

Table 2 Sensory analysis of pedada juice

\begin{tabular}{cccccr}
\hline \multirow{2}{*}{ Sample } & \multicolumn{5}{c}{ Parameters } \\
\cline { 2 - 6 } & Color & Taste & Aroma & Texture & Overall Acceptance \\
\hline P1 & $3.35 \pm 0.68^{\mathrm{b}}$ & $1.70 \pm 0.77^{\mathrm{a}}$ & $2.60 \pm 0.69^{\mathrm{a}}$ & $4.62 \pm 0.64^{\mathrm{b}}$ & $2.70 \pm 0.74^{\mathrm{a}}$ \\
P2 & $3.05 \pm 0.67^{\mathrm{a}}$ & $3.25 \pm 1.00^{\mathrm{b}}$ & $3.00 \pm 0.78^{\mathrm{b}}$ & $4.45 \pm 0.75^{\mathrm{ab}}$ & $3.23 \pm 0.72^{\mathrm{b}}$ \\
P3 & $3.07 \pm 0.76^{\mathrm{a}}$ & $3.45 \pm 1.02^{\mathrm{bc}}$ & $2.97 \pm 0.85^{\mathrm{b}}$ & $4.57 \pm 0.65^{\mathrm{ab}}$ & $3.47 \pm 0.72^{\mathrm{ab}}$ \\
P4 & $3.38 \pm 0.49^{\mathrm{b}}$ & $1.50 \pm 0.60^{\mathrm{a}}$ & $2.58 \pm 0.77^{\mathrm{a}}$ & $4.33 \pm 0.82^{\mathrm{ab}}$ & $2.45 \pm 0.50^{\mathrm{a}}$ \\
P5 & $3.02 \pm 0.80^{\mathrm{a}}$ & $3.70 \pm 0.12^{\mathrm{cd}}$ & $3.02 \pm 0.79^{\mathrm{b}}$ & $4.30 \pm 0.85^{\mathrm{a}}$ & $3.57 \pm 0.89^{\mathrm{b}}$ \\
P6 & $3.22 \pm 0.80^{\mathrm{b}}$ & $4.00 \pm 0.76^{\mathrm{d}}$ & $3.17 \pm 0.78^{\mathrm{b}}$ & $4.42 \pm 0.74^{\mathrm{ab}}$ & $3.65 \pm 0.88^{\mathrm{b}}$ \\
\hline
\end{tabular}

Note: different letter on the same column indicate a significant difference at $p<0.05$ 
yaitu menghasilkan warna kuning kecoklatan akibat karamelisasi. Hasil penilaian subjektif ini justru berbanding terbalik dengan hasil objektif menggunakan kromameter yang menunjukkan tingkat kecerahan minuman dengan penambahan gula lebih tinggi, panelis justru melihat perubahan warna kecoklatan ini sebagai penyimpangan dari warna seharusnya.

Burdurlu dan Karadeniz (2012) melaporkan bahwa banyak produk makanan yang warnanya mulai menggelap selama musim panas dan saat disimpan, dalam penelitiannya mengenai konsentrat sari buah apel dengan penambahan gula yaitu akumulasi warna cokelat selama pemrosesan termal disebabkan oleh pencokelatan enzimatik tetapi selama penyimpanan disebabkan oleh reaksi non enzimatik. Reaksi karamelisasi terjadi pada perlakuan panas gula dengan suhu yang tinggi. Reaksi ini melibatkan karamelisasi, degradasi asam askorbat dan mailard reaksi. Reaksi tersebut dapat meningkatkan nilai karakteristik sensori pada warna sehingga memengaruhi penerimaan produk oleh konsumen.

\section{Aroma sari buah pedada}

Aroma merupakan respon yang muncul ketika senyawa volatil produk atau pangan masuk ke rongga hidung dan dirasakan oleh sistem olfaktori (Tarwendah 2017). Berdasarkan hasil penelitian ini diperoleh bahwa tingkat penerimaan kesukaan terhadap parameter aroma pada sampel P2 dan P3 nyata lebih disukai aromanya dibandingkan dengan sampel P1 (kontrol 1) dan nilai P5 dan P6 juga lebih disukai dibandingkn P4 (kontrol 2) (Table 2). Jika dilihat secara keseluruhan hasil analisis karakteristik sensori parameter aroma menunjukkan bahwa aroma minuman sari buah sampel P6 (formulasi pedada $200 \mathrm{~g}$ dan penambahan gula $70 \%$ ) adalah yang lebih banyak disukai. Formulasi ini merupakan sari buah pedada dengan penambahan gula terbesar. Zuliana et al. (2016) melaporkan bahwa proses karamelisasi dan reaksi mailard pada proses pengolahan gula menghasilkan aroma dengan flavour gula karena komponen gula menjadi cair dan berwarna cokelat ketika dipanaskan. Flavour karamel akan memengaruhi tingkat kesukaan terhadap aroma produk. Aroma karamel akan meningkatkan kesukaan terhadap produk pangan. Sehingga perpaduan aroma karamel gula bercampur dengan aroma khas pedada meningkatkan penerimaan terhadap variabel aroma.

Berdasarkan penelitian yang dilakukan oleh Octaviani dan Rahayuni (2014) diketahui bahwa aroma sari buah buni dengan penambahan gula tertinggi $(20 \mathrm{~g})$ memiliki nilai penerimaan tertinggi, dibandingkan pada kelompok kontrol. Komposisi gula tertentu menyebabkan aroma produk disukai oleh panelis. Hal tersebut dikarenakan komposisi gula memengaruhi pembentukan aroma pada suatu produk. Komponen gula pada produk akan mengalami karamelisasi jika dipanaskan baik dalam suasana asam ataupun basa dan akan memengaruhi aroma produk.

\section{Rasa sari buah pedada}

Komponen yang paling menentukan penerimaan suatu produk adalah rasa, sehingga berpengaruh terhadap keputusan akhir konsumen untuk menerima atau menolaksuatu produk makanan. Penilaian rasa produk pangan merupakan hasil kerjasama indera-indera sensori yang ikut berperan dalam pengamatan bahan pangan (Septiawan 2019). Variabel rasa sari buah pedada dalam penelitian ini dilihat berdasarkan penilaian subjektif panelis berdasarkan mutu hedonik dengan skor 1-5 kategori sangat asam hingga asam manis. Hasil uji organoleptik sari buah pedada disajikan pada Table 2.

Hasil diperoleh tingkat penilaian terhadap parameter rasa sampel meningkat seiring penambahan gula. Sampel P4 dan P1 (kontrol) nyata lebih asam dibandingkan dengan sampel P2, P3, P5 dan P6. Sampel P5 dan P6 nyata berbeda dengan sampel lainnnya dengan penilaian rasa agak manis keasaman. Rata-rata nilai panelis diketahui formulasi buah pedada $200 \mathrm{~g}$ dengan penambahan gula $70 \%$ yang terbaik dari segi rasa. Buah pedada memiliki ciri khas buahnya yang asam sehingga banyak yang tidak menyukai buah tersebut (Ahmed et al. 2010). Sifat asam yang dimiliki oleh buah pedada menghasilkan 
kandungan vitamin $\mathrm{C}$ yang tinggi pula yaitu sebesar 56,74 mg/100 g (Ramadani et al. 2019). Minuman sari buah pedada dapat diukur tingkat keasamannya yaitu dengan kadar pH (BSN 2004) berkisar 0-6,4 dikategorikan asam; 6,5-7,5 dikategorikan netral; 7,6-14 dikategorikan basa. Hasil penelitian yang telah dilakukan yaitu semakin besar konsentrasi gula ditambahkan, maka sari buah pedada memiliki derajat keasaman $(\mathrm{pH})$ yang tinggi. Begitu juga sebaliknya, semakin sedikit konsentrasi gula yang ditambahkan, maka sari buah pedada akan memiliki derajat keasaman $(\mathrm{pH})$ yang rendah.

Menurut Pertiwi dan Susanto (2014), banyaknya gula yang ditambahkan sejalan dengan $\mathrm{pH}$ yang meningkat. Hal ini terjadi karena ion $\left[\mathrm{H}^{+}\right]$yang membentuk asam akan berkurang, sehingga $\mathrm{pH}$ bahan akan meningkat.semakin sedikit formulasi gula yang ditambahkan atau sama sekali tanpa penambahan gula pada sari buah pedada maka kadar $\mathrm{pH}$ akan semakin kecil (asam). Begitu juga sebaliknya, semakin banyak formulasi gula yang ditambahkan maka kadar pH akan semakin meningkat (basa).

Penambahan gula sukrosa juga bertujuan untuk meningkatkan cita rasa atau flavour bahan makanan dan minuman sehingga dapat menutupi rasa asam pada bahan makanan yang berasa asam. Komposisi yang tepat proses pemasakan ini menyeimbangkan rasa asam manis dan menimbulkan rasa dan aroma yang enak sehingga produk akan lebih disukai (Normah dan Noorasma 2018; Febriyanti et al. 2018).

\section{Tekstur sari buah pedada}

Tekstur merupakangabungan daribentuk, ukuran, jumlah dan unsur pembetukan produk yang dapat dirasakan oleh indera perasa, peraba, dan pengecapan (Tarwendah 2017). Variabel tekstur sari buah pedada dalam penelitian ini dilihat berdasarkan penilaian subjektif panelis berdasarkan mutu hedonik dengan skor 1-5 kategori sangat kental hingga cair. Hasil Uji tekstur disajikan pada Table 2. Berdasarkan nilai rata-rata panelis diketahui semua sampel tidak berbeda dari segi tekstur, semua sampel termasuk dalam kategori cair. Hasil penelitian yang telah dilakukan pada analisis viskositas yaitu semakin banyak konsentrasi gula yang ditambahkan maka akan semakin kental sari buah, namun seluruh sampel masuk dalam kategori cair karena nilai viskositas minuman sari buah pedada secara keseluruhan tidak banyak menunjukkan perbedaan di setiap perlakuannya, hanya saja mengalami peningkatan dengan semakin besarnya konsentrasi gula yang ditambahkan. Gula mempunyai sifat hidrofilik yang disebabkan oleh adanya gugus hidroksil dalam struktur molekulnya. Gugus hidroksil tersebut akan berikatan dengan molekul air melalui ikatan hidrogen, akibatnya air yang terdapat dalam bahan pangan tersebut akan berkurang sehingga tekstur minuman akan semakin kental (Winarno 1992)

Yunita dan Achir (2013) melaporkan bahwa gula berfungsi sebagai pemberi rasa sekaligus pengawet alami dengan cara mengikat sebagian air di dalam pangan sehingga water activity $\left(\mathrm{a}_{\mathrm{w}}\right)$ berkurang. Gula sebagai bahan penstabil dapat meningkatkan kekentalan produk pangan sebab pektin yang terdapat di dalam pangan yang bercampur dengan gula yang dipanaskan dengan suhu tinggi menciptakan tekstur yang lebih kental. Sehingga panelis memilih produk sari buah pedada tanpa penambahan gula sebab lebih cair dan cocok untuk dikonsumsi secara langsung.

\section{Penerimaan sari buah pedada secara keseluruhan}

Variabel penerimaan keseluruhan sari buah pedada dalam penelitian ini dilihat berdasarkan penilaian subjektif panelis berdasarkan hedonik atau tingkat kesukaan dengan skor 1-5 kategori sangat tidak suka hingga sangat suka. Penerimaan panelis meningkat seiring penambahan gula yang diberikan dalam penelitian ini. Hasil ratarata tingkat penilaian terhadap penerimaan secara keseluruhan sampel P5 dan P6 nyata lebih disukai dibandingkan sampel lainnya (P4, P1, P2 dan P3) ditandai dengan nilai skor penerimaan secara keseluruhan sampel P5 yaitu 3,57 dan sampel P6 yaitu 3,65 yang termasuk dalam kategori suka. Panelis lebih menyukai formulasi buah pedada $200 \mathrm{~g}$ dengan penambahan gula $70 \%$ jika dibandingkan 
antara seluruh parameter karena rasanya yang manis keasaman dapat diterima oleh panelis. Rasa sangat menentukan penerimaan suatu produk, karena itu minuman sari buah pedada dengan penambahan gula $70 \%$ adalah komposisi yang paling disukai oleh panelis. Hasil penelitian yang dilakukan oleh Minh (2019) tentang produksi sari buah pedada menunjukkan bahwa cita rasa buah pedada dengan gula yang terlarut sebanyak $18{ }^{\circ}$ Brix paling banyak disukai oleh panelis. Berdasarkan SNI 3719:2014 tentang minuman sari buah bahwa aroma, rasa dan warna minuman sari buah harus khas dan normal serta tidak memiliki aroma, rasa, dan warna yang menyimpang.

\section{KESIMPULAN}

Hasil penilaian objektif terhadap $\mathrm{pH}$, viskositas dan warna penambahan gula memberikan pengaruh yang nyata terhadap karakteristik produk sari buah pedada. Sedangkan berdasarkan penilaian subjektif penambahan gula pada pembuatan sari buah pedada hanya berpengaruh nyata terhadap variabel warna aroma rasa tapi tidak berbeda nyata untuk penerimaan tekstur. Formulasi terbaik dalam penelitian ini adalah sampel P6 (buah pedada $200 \mathrm{~g}$ dengan penambahan gula 70\%) menghasilkan nilai pH 3,20 (asam), viskositas $2,88 \mathrm{cp}$, nilai $L^{*} 47,19$, warna agak disukai, aroma agak disukai, rasa asam manis, tekstur cair dan penerimaan secara keseluruhan disukai oleh panelis.

\section{UCAPAN TERIMAKASIH}

Ucapan terimakasih kepada Kemenristek Dikti yang telah mendanai penelitian melalui program hibah Penelitian Dosen Pemula pendanaan tahun 2019 atas nama Dini Wulan Dari, serta kepada seluruh laboratorium dan panelis yang membantu dalam terlaksananya penelitian ini.

\section{DAFTAR PUSTAKA}

Ahmed R, Moushumi SJ, Ahmed H, Ali M, Haq WM, Jahan R, Rahmatullah M. 2010. Serum glucose and lipid profiles in rats following administration of Sonneratia caseolaris (L.) engl. (Sonneratiaceae) leaf powder in diet. Advanes in Natural and
Applied Sciences. 4(2): 171-173.

Andriani D, Afendi R, Harun N. 2016. Mutu sirup buah pedada (Sonneratia caseolaris) selama penyimpanan dengan penambahan natrium benzoat. Jurnal Online Mahasiswa Faperta. 3(1).

[BSN] Badan Standardisasi Nasional. 2004. Cara Uji $p H$ ( $p H$ meter) SNI Nomor 06-6989.11-2004. Jakarta (ID): Badan Standardisasi Nasional.

[BSN] Badan Standardisasi Nasional. 2008. Cara Uji Viskositas (Viskometer Kapiler) SNI Nomor 0936:2008. Jakarta (ID): Badan Standardisasi Nasional.

Burdurlu HS, Karadeniz F. 2012. Effect of storage on nonenzymatic browning of apple juice concentrates. Food Chemistry. 80: 91-97.

Dari DW, Ananda M, Junita D. 2020b. Karakteristik kimia sari buah pedada (Sonneratia caseolaris) selama penyimpanan. Jurnal Teknologi Pertanian Andalas. 24(2): 189-195.

Dari DW, Ramadani DT, Aisah A. 2020a. Kandungan gizi dan aktivitas antioksidan permen jelly buah pedada (Sonneratia caseolaris) dengan penambahan karagenan. Jurnal Akademika Baiturrahim Jambi. 9(2): 154-165.

Farikha IN, Anam C, Widowati E. 2013. Pengaruh jenis dan konsentrasi bahan penstabil alami terhadap karakteristik fisikokimia sari buah naga merah (Hylocereus polyrhizus) selama penyimpanan. Jurnal Teknosains Pangan. 2(1): 30-38.

Febriyanti N, Caronge MW, Lahming. 2018. Pengaruh lama pengeringan dan berbagai jenis gula terhadap kualitas manisan tomat (Lycopersium esculentum). Jurnal Pendidikan Teknologi Pertanian. 4(1): 8694.

Hutching JB. 1999. Food and Appearance. Second edition. Gaitersburg, Mayland: Aspen Publ. Inc.

Indriaty F, Assah YF. 2015. Pengaruh penambahan gula dan sari buah terhadap minuman serbuk daging buah pala. Jurnal Penelitian Teknologi Industri. 7(1): 49-60.

Jariyah, Nurismanto R, Pratiwi NFD. 2019. Pengaruh penambahan CMC terhadap 
karakteristik es krim jus buah pedada dan kelapa muda. Jurnal Teknologi dan Industri Hasil Pertanian. 24 (1): 51-58.

Jariyah, Widjanarko SB, Yunianta, Estiasih T. 2015. Phytochemical and acute toxicity studies of ethanol extract from Pedada (Sonneratia caseoalris) fruit flour (PFF). International Journal on Advanced Science Engineering Information Technology. 5(2): 95-98.

Jariyah, Widjanarko SB, Yunianta, Estiasih T. 2014. Hypoglycemic effect of pedada (Sonneratia caseolaris) fruit flour (PFF) inalloxan-induced diabetic rats. International Journal of Pharmacy Technology Research. 7(1): 31-40.

Kaemba A, Suryanto E, Mamuaja CF. 2017. Karakteristik fisiko-kimia dan aktivitas antioksidan beras analog dari sagu baruk (Arenga microcarpha) dan ubi jalar ungu (Ipomea Batatas L.Poiret). Jurnal Ilmu dan Teknologi Pangan. 5(01): 74-81.

Kiayi GS. 2018. Konsentrasi asam sitrat terhadap mutu sari buah mangga Indramayu. Gorontalo Agriculture Technology Journal. 1(1): 29-36.

Manalu RDE, Salamah E, Retiaty F, Kurniawati N. 2013. Kandungan zat gizi makro dan vitamin produk buah pedada (Sonneratia caseolaris). Penelitian Gizi dan Makanan. 36 (2): 135-140.

Minh NP. 2019. Invesitgation of mangrove apple (Sonneratia caseolaris) juice production. Journal of Pharmaceutical Sciences and Research. 11(3): 809-812.

Normah I, Noorasma M. 2018. Flavor improvement of mud clam (Polymesoda erosa) hydrolysate by using maillard reaction. International Food Research Journal. 25(3): 1146-1152.

Octaviani LF, Rahayuni A. 2014. Pengaruh berbagai konsentrasi gula terhadap aktivitas antioksidan dan tingkat penerimaan sari buah buni (Antidesma bunius). Journal of Nutrition College. 3(4): 958-965.

Pertiwi MFD, Susanto WH. 2014. Pengaruh proporsi (buah:sukrosa) dan lama osmosis terhadap kualitas sari buah stroberi (Fragaria vesca L). Jurnal Pangan dan Agroidustri. 2(2): 82-90.
Pradana GW, Jacoeb AM, Suwandi R. 2017. Karakteristik tepung pati dan pektin buah pedada serta aplikasinya sebagai bahan baku pembuatan edibe film. Jurnal Pengolahan Hasil Perikanan Indonesia. 20(3): 609-619.

Pratama SB, Wijana S, Febriyanto A. 2012. Studi pembuatan sirup tamarillo (Kajian perbandingan buah dan konsentrasi gula). Jurnal Industri. 1(3): 181-194.

Prihanto AW. 2011. Perbandingan Aktivitas Antibakteri Penicillium notatum ATCC 28089 dengan Penicillium sp. R1M yang diisolasi dari mangrove Sonneratia caseolaris. Jurnal Pengolahan Hasil Perikanan Indonesia. 15(1): 66-70.

Rakhmawati R, Yunianta Y.2015. Pengaruh proporsi buah: air dan lama pemanasan terhadap aktivitas antioksidan sari buah kedondong (Spondias dulcis). Jurnal Pangan Dan Agroindustri. 3(4):16821693.

Ramadani DT, Meilina M, Arsita Y, Dari DW, Safitri N. 2019. Pengaruh penambahan gula terhadap karakteristik kimia sirup pedada (Sonneratia Caseolaris). Jambi (ID): Prosiding Seminar Nasional Gizi. 44-50

Ramadani DT, Dari DW, Aisah A. 2020. Daya terima permen jelly buah pedada (Sonneratia caseolaris) dengan penambahan karagenan. Jurnal Akademika Baiturrahim Jambi. 9(1): 1524.

Septiawan Y. 2019. Pengaruh konsentrasi sukrosa dan lama fermentasi terhadap karakteristik kombu salak bongkok (Salacca edulis. Reinw). Jurnal Agroscience. 9(1): 1976-4661.

Tarwendah IP. 2017. Studi komparasi atribut sensoris dan kesadaran merk produk pangan. Jurnal Pangan dan Agroindustri. 5(2): 66-73.

Tjandra. 2016. Mengenal Hutan Mangrove. Bogor (ID): Penerbit Pakar Media.

Visita BF, Putri WDR. 2014. Pengaruh penambahan bubuk mawar merah (Rosa damascene Mill) dengan jenis bahan pengisi berbeda pada cookies. Jurnal Pangan dan Agroindustri. 2(1):39-46.

Wiyono TS, Kartikawati D. 2017. Pengaruh 
metode ekstraksi sari nanas secara langsung dan osmosis dengan variasi perebusan terhadap kualitas sirup nanas (Ananas comosus L.). Serat Acitya. 6(2):108-118.

Yunita S, Achir S. 2013. Pengaruh jumlah pektin dan gula terhadap sifat organoleptik jam buah naga merah
(Hylocereus polyrhizus). Jurnal Tata Boga. 2 (2): 1-10.

Zuliana C, Widyastuti E, Susanto H. 2016. Pembuatan gula semut kelapa (Kajian pH gula kelapa dan konsentrasi natrium bikarbonat). Jurnal Pangan dan Agroindustri. 4(1): 109-119. 